\title{
Sphingomonas yunnanensis sp. nov., a novel Gram-negative bacterium from a contaminated plate
}

\author{
Yu-Qin Zhang,† Yi-Guang Chen, Wen-Jun Li, Xin-Peng Tian, Li-Hua Xu \\ and Cheng-Lin Jiang
}

Correspondence

Wen-Jun Li

wjli@ynu.edu.cn or

lihxu@ynu.edu.cn
The Key Laboratory for Microbial Resources of Ministry of Education, Yunnan Institute of Microbiology and Laboratory for Conservation and Utilization of Bio-Resources, Yunnan University, Kunming, Yunnan 650091, PR China
The genus Sphingomonas was first proposed by Yabuuchi et al. (1990) and its description was later emended several times by Takeuchi et al. (1993, 2001), Yabuuchi et al. (2002) and Busse et al. (2003). Members of the genus Sphingomonas are yellow-pigmented, Gram-negative, aerobic, non-sporeforming, non-fermentative, motile or non-motile rods and are characterized chemotaxonomically by the presence of ubiquinone Q-10 and 2-hydroxy fatty acids and by the absence of 3-hydroxy fatty acids. In this paper, we report the results of our polyphasic taxonomic study on strain YIM

Published online ahead of print on 24 June 2005 as DOI 10.1099/ ijs.0.63697-0.

†Present address: Institute of Medicinal Biotechnology, Chinese Academy of Medical Sciences \& Peking Union Medical College, Beijing 100050, PR China.

The GenBank/EMBL/DDBJ accession number for the $16 \mathrm{~S}$ rRNA gene sequence of strain YIM $003^{\top}$ is AY894691.

A two-dimensional thin-layer chromatogram of the phosphate-containing lipids of strain YIM $003^{\top}$ is available as a supplementary figure in IJSEM Online.
$003^{\mathrm{T}}$, which was picked from a contaminated plate in our laboratory. The $16 \mathrm{~S}$ rRNA gene sequence of strain YIM $003^{\mathrm{T}}$, containing the signature nucleotides that are specific for the genus Sphingomonas (Takeuchi et al., 2001), combined with the morphological, physiological and chemotaxonomic characteristics and phylogenetic analyses demonstrated that the strain should be assigned to a novel species of the genus Sphingomonas.

During the conservation of some useful microbes, with different bioactivities, in a refrigerator in our laboratory, one yellow-pigmented colony was found on an ISP2 agar plate. The strain, YIM $003^{\mathrm{T}}$, grew well on ISP2 plates (Shirling \& Gottlieb, 1966) at $28^{\circ} \mathrm{C}$. Cells used for biochemical and molecular systematic analysis were grown in shake flasks (about 150 r.p.m.) containing ISP2 medium at $28^{\circ} \mathrm{C}$ for 4 days. Stock cultures were maintained at $4{ }^{\circ} \mathrm{C}$ using ISP2 slants and as glycerol suspensions $(20 \%, \mathrm{v} / \mathrm{v})$ at $-20^{\circ} \mathrm{C}$.

Strain YIM $003^{\mathrm{T}}$ was incubated on ISP2 and nutrient agar media for observation of cells and colony morphology, 
respectively. The morphology of strain YIM $003^{\mathrm{T}}$ was observed under a light microscope (model BH 2; Olympus) and using a transmission electron microscope (Hitachi $\mathrm{H}$ 800 ) after $48 \mathrm{~h}$ growth on ISP2 agar medium. The cells of strain YIM $003^{\mathrm{T}}$ were aerobic, motile, non-spore-forming and short-rod-shaped (about $0 \cdot 4-0.6 \mu \mathrm{m}$ wide and $0 \cdot 8-1 \cdot 0 \mu \mathrm{m}$ long), each bearing a single polar flagellum. Strain YIM $003^{\mathrm{T}}$ formed yellow colonies with a maximum diameter of about $5 \mathrm{~mm}$ after incubation at $28^{\circ} \mathrm{C}$ for $48 \mathrm{~h}$ on ISP2 agar. Colonies on ISP2 medium were circular, slightly convex and opaque. No diffusible pigments were observed on any medium. The cellular morphology of strain YIM $003^{\mathrm{T}}$ is largely like that of reference strain Sphingomonas phyllosphaerae $\mathrm{FA}^{\mathrm{T}}{ }^{\mathrm{T}}$ (Rivas et al., 2004).

Gram-staining was determined as described by Moaledj (1986), with $48 \mathrm{~h}$ cultures. All of the other physiological and biochemical tests were performed at $28^{\circ} \mathrm{C}$ as described previously ( $\mathrm{Li}$ et al., 2004). The $\mathrm{pH}, \mathrm{NaCl}$ concentration and temperature ranges for growth were $\mathrm{pH} 6 \cdot 5-8 \cdot 0,0-5 \%$ and $0-40{ }^{\circ} \mathrm{C}$ using ISP2 as the basic medium; the optimum $\mathrm{pH}$, $\mathrm{NaCl}$ concentration and temperature range for growth were $\mathrm{pH} 7 \cdot 0-7 \cdot 5,0-1 \%$ and $28^{\circ} \mathrm{C}$. The isolate was catalase- and oxidase-positive. Methyl red and Voges-Proskauer tests and urease, melanin, tyrosinase and Tween 80 esterase production were negative, while milk peptonization and coagulation, nitrate reduction and Tween 20 esterase tests were positive. Details of the physiological and biochemical properties are given in Table 1 and in the species description.

The respiratory isoprenoid quinones were isolated, purified and analysed as described by Lee et al. (2001). Only the phosphate-containing fraction was analysed according to the method of Ventosa et al. (1993), using molybdenum blue as the spray reagent; the designations were as referred to by Busse et al. (1999) and Rivas et al. (2004). Fatty acid analysis was performed using the standard method of Sasser (1990) and the results were compared with the database of fatty acids in the Sherlock Microbial Identification System (MIDI). Genomic DNA was isolated and purified by using the method of Marmur (1961). The DNA G +C content of strain YIM $003^{\mathrm{T}}$ was measured by using the thermal denaturation method (Marmur \& Doty, 1962), with a Shimadzu-1601 spectrophotometer.

The major respiratory lipoquinone of strain YIM $003^{\mathrm{T}}$ was ubiquinone Q-10. The phosphate-containing lipids detected were diphosphatidylglycerol, phosphatidylglycerol, phosphatidylethanolamine, phosphatidylcholine, sphingoglycolipid and one unidentified phospholipid (see the two-dimensional thin-layer chromatogram available as a supplementary figure in IJSEM Online). The fatty acid profile of strain YIM $003^{\mathrm{T}}$ was composed mainly of $\mathrm{C}_{18: 1} \omega 7 \mathrm{c}$

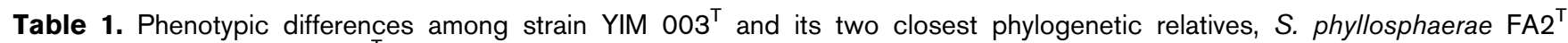
and S. adhaesiva DSM $7418^{\top}$

Data for reference strains were taken from Rivas et al. (2004) (S. phyllosphaerae FA2 ${ }^{\mathrm{T}}$ ) and Yabuuchi et al. (1990) (S. adhaesiva DSM $7418^{\mathrm{T}}$ ). All three strains are aerobic, Gram-negative, yellow-pigmented, non-spore-forming, motile rod-shaped bacteria that contain sphingoglycolipid and have ubiquinone Q-10 as the major respiratory lipoquinone. +, Positive; -, negative; W, weakly positive; ND, not determined.

\begin{tabular}{|c|c|c|c|}
\hline Characteristic & S. yunnanensis YIM $003^{\mathrm{T}}$ & S. phyllosphaerae $\mathrm{FA}^{\mathrm{T}}$ & S. adhaesiva DSM $7418^{\mathrm{T}}$ \\
\hline Nitrite from nitrate & + & - & - \\
\hline Gelatinase & - & - & + \\
\hline \multicolumn{4}{|l|}{ Acid from: } \\
\hline Glycerol & - & - & + \\
\hline Maltose & - & + & + \\
\hline Rhamnose & - & + & + \\
\hline Salicin & - & - & + \\
\hline Galactose & + & + & - \\
\hline Trehalose & - & + & + \\
\hline Tween 20 esterase & + & - & ND \\
\hline Oxidase & + & $\mathrm{W}$ & + \\
\hline Milk peptonization and coagulation & + & - & - \\
\hline Polar lipids* & $\begin{array}{l}\text { PE, PG, DPG, PC, } \\
\text { SGL, PL }\end{array}$ & $\begin{array}{l}\text { PE, PG, DPG, PC, } \\
\text { SGL, PL1, PL2 }\end{array}$ & $\begin{array}{l}\text { PME, PE, PG, DPG, PDE, PC, } \\
\text { SGL, APL1, PL1, PL2, PL3, GL2 }\end{array}$ \\
\hline DNA G + C content $(\mathrm{mol} \%)$ & $67 \cdot 5$ & 61 & $67 \cdot 2$ \\
\hline
\end{tabular}

*Abbreviations: APL1, unidentified aminophospholipid; DPG, diphosphatidylglycerol; GL2, unidentified glycolipid; PC, phosphatidylcholine; PDE, phosphatidyldimethylethanolamine; PE, phosphatidylethanolamine; PG, phosphatidylglycerol; PL, PL1, PL2, PL3, unidentified phospholipids; PME, phosphatidylmonomethylethanolamine; SGL, sphingoglycolipid. 
$(59 \cdot 8 \%), \mathrm{C}_{16: 0}(9 \cdot 9 \%)$, ai- $\mathrm{C}_{17: 0}(5 \cdot 3 \%), \mathrm{i}-\mathrm{C}_{17: 0}(4 \cdot 4 \%)$ and $\mathrm{C}_{14: 0} 2-\mathrm{OH}(15 \cdot 8 \%)$. The DNA G $+\mathrm{C}$ content was determined to be $67 \cdot 5 \mathrm{~mol} \%$.

The 16S rRNA gene sequence of the isolate was amplified by a PCR using conserved primers close to the $3^{\prime}$ and $5^{\prime}$ ends of the gene, as described previously (Cui et al., 2001). Multiple alignments with sequences of a broad selection of members of the family Sphingomonadaceae, and calculations of levels of sequence similarity, were carried out using CLUSTAL X software (Thompson et al., 1997). A phylogenetic tree was reconstructed using the neighbour-joining method of Saitou \& Nei (1987) from $K_{\text {nuc }}$ values (Kimura, 1980, 1983). The topology of the phylogenetic tree was evaluated by using Felsenstein's bootstrap resampling method (Felsenstein, 1985) with 1000 replicates.

A nearly-complete $16 \mathrm{~S}$ rRNA gene sequence (1415 bp) for strain YIM $003^{\mathrm{T}}$ was obtained and subjected to a comparative analysis. Phylogenetically, strain YIM $003^{\mathrm{T}}$ was closest to $S$. phyllosphaerae $\mathrm{FA}^{\mathrm{T}}$ and Sphingomonas adhaesiva DSM $7418^{\mathrm{T}}$, and the sequence similarities to the latter two type strains were 98.2 and $98.0 \%$, respectively. They formed a distinct subclade in the phylogenetic tree of all members of the genus Sphingomonas (see Fig. 1; not all of the relatives are shown). Additionally, the 16S rRNA gene sequence of strain YIM $003^{\mathrm{T}}$, containing the signature nucleotides specific for the genus Sphingomonas cluster I (Takeuchi et al., 2001), such as 52-359 (C-G), $134(\mathrm{G})$, $593(\mathrm{G}), 987-1218(\mathrm{G}-\mathrm{C}), 990-1215(\mathrm{U}-\mathrm{G})$, confirmed that the tested strain should be classified in the genus Sphingomonas.

DNA-DNA hybridizations were carried out among strains YIM $003^{\mathrm{T}}$, S. phyllosphaerae $\mathrm{FA} 2^{\mathrm{T}}$ and $S$. adhaesiva DSM $7418^{\mathrm{T}}$ by applying the optical renaturation method (De Ley et al., 1970; Huß et al., 1983; Jahnke, 1992) and using a UVVis spectrophotometer (model UV1601; Shimadzu) under optimal hybridization conditions. The values obtained were respectively 59 and $26 \%$ (repeated twice) for DNA-DNA relatedness between strain YIM $003^{\mathrm{T}}$ and S. phyllosphaerae $\mathrm{FA} 2^{\mathrm{T}}$ and S. adhaesiva DSM $7418^{\mathrm{T}}$. Both values were lower than $70 \%$, which is the value considered to be the threshold for the delineation of genospecies (Stackebrandt \& Goebel, 1994), and clearly indicated that the novel isolate, YIM $003^{\mathrm{T}}$, belonged to a different genomic species with respect to S. phyllosphaerae $\mathrm{FA}^{\mathrm{T}}$ and S. adhaesiva DSM $7418^{\mathrm{T}}$.
On the basis of morphological, phylogenetic and chemotaxonomic data, strain YIM $003^{\mathrm{T}}$ should be placed in the genus Sphingomonas. The differences between strain YIM $003^{\mathrm{T}}$ and the two most closely related species of the genus Sphingomonas justify the description of a novel species, for which the name Sphingomonas yunnanensis sp. nov. is proposed.

\section{Description of Sphingomonas yunnanensis sp. nov.}

Sphingomonas yunnanensis (yun.nan.en'sis. N.L. fem. adj. yunnanensis pertaining to Yunnan, a province of south-west China).

Cells are aerobic, motile, non-spore-forming and short-rodshaped and about $0 \cdot 4-0 \cdot 6 \mu \mathrm{m}$ wide and $0 \cdot 8-1 \cdot 0 \mu \mathrm{m}$ long with single polar flagella. Forms yellow-pigmented colonies with a maximum diameter of about $5 \mathrm{~mm}$ after incubation at $28^{\circ} \mathrm{C}$ for $48 \mathrm{~h}$ on ISP2 agar. Colonies on ISP2 medium are circular, slightly convex and opaque. The optimum growth $\mathrm{pH}, \mathrm{NaCl}$ concentration and temperature are $7 \cdot 0-7 \cdot 5,0-1 \%$ and $28{ }^{\circ} \mathrm{C}$, respectively. Catalaseand oxidase-positive. Starch is not decomposed. Positive for lipase, $\beta$-glucosidase, $\beta$-galactosidase, $\alpha$-galactosidase, $\alpha$-glucosidase, $\alpha$-maltosidase, arylamidase, milk peptonization and coagulation, nitrate reduction, Tween 20 esterase and hydrolysis of aesculin. Negative for ornithine decarboxylase, arginine dihydrolase, lysine decarboxylase, urease, indole production, $\beta$-glucuronidase and gelatinase, in methyl red and Voges-Proskauer tests and for tyrosinase, Tween 80 esterase, melanin, $\mathrm{H}_{2} \mathrm{~S}$ and indole production. Acetamide, malonate, glucose, galactose, mannose, xylose, ribose, lactose, dextrin, amygdalin, fructose and $\mathrm{N}$-acetyl $\alpha$ glucosamine can be utilized as sole carbon sources. Acid is produced from acetamide, lactose, galactose and mannose, whereas L-arabitol, D-arabitol, L-arabinose, galacturonate, phenol red, mannitol, 5-ketogluconate, maltose, sucrose, trehalose, rhamnose, inositol, palatinose, cellobiose and sorbitol are not used. The major respiratory lipoquinone is ubiquinone Q-10. The polar lipids contain diphosphatidylglycerol, phosphatidylglycerol, phosphatidylethanolamine, phosphatidylcholine, sphingoglycolipid and one unidentified phospholipid. The cellular fatty acid profile is composed mainly of $\mathrm{C}_{18: 1} \omega 7 \mathrm{c}(59 \cdot 8 \%), \mathrm{C}_{16 \cdot 0}(9 \cdot 9 \%)$, ai$\mathrm{C}_{17: 0}(5 \cdot 3 \%)$, i- $\mathrm{C}_{17: 0}(4 \cdot 4 \%)$ and $\mathrm{C}_{14: 0} 2-\mathrm{OH}(15 \cdot 8 \%)$. The DNA G + C content is $67 \cdot 5 \mathrm{~mol} \%$.

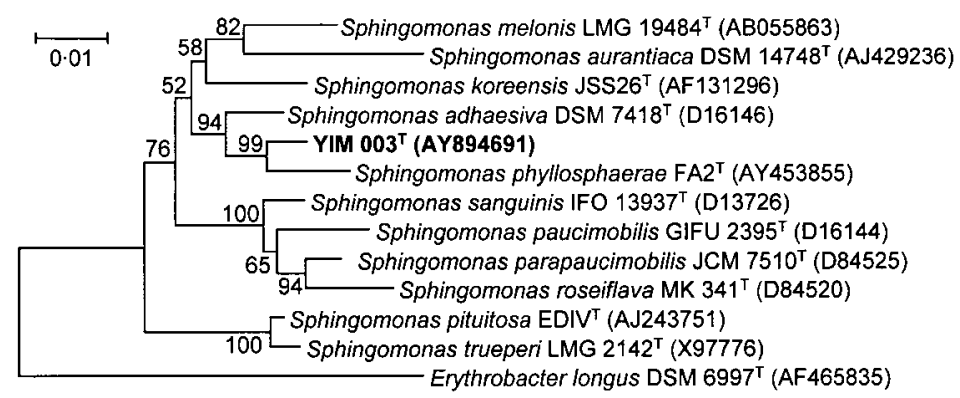

Fig. 1. Phylogenetic dendrogram obtained by distance matrix analysis of $16 \mathrm{~S}$ rRNA gene sequences, showing the position of strain YIM $003^{\top}$ among phylogenetic neighbours. Numbers on branch nodes are bootstrap values (1000 resamplings). The sequence of Erythrobacter longus DSM $6997^{\top}$ was used as the outgroup. Bar, $1 \%$ sequence divergence. 
The type strain, YIM 003 ${ }^{\mathrm{T}}\left(=\right.$ CCTCC AB $204064^{\mathrm{T}}=$ KCTC $12346^{\mathrm{T}}$ ), was isolated from a contaminated plate. CCTCC is the China Center of Type Culture Collection (Wuhan City, Hubei Province, China).

\section{Acknowledgements}

The authors are grateful to Dr Encarna Velázquez for kindly providing the type strain of $S$. phyllosphaerae and also to Dr Hans-Jürgen Busse for his many kind suggestions and help. This research was supported by the National Basic Research Program of China (project no. 2004CB719601), the National Natural Science Foundation of China (project no. 30270004) and the Yunnan Provincial Natural Science Foundation (project no. 2004 C0002Q).

\section{References}

Busse, H.-J., Kämpfer, P. \& Denner, E. B. M. (1999). Chemotaxonomic characterisation of Sphingomonas. $J$ Ind Microbiol Biotechnol 23, 242-251.

Busse, H.-J., Denner, E. B. M., Buczolits, S., Salkinoja-Salonen, M., Bennassar, A. \& Kämpfer, P. (2003). Sphingomonas aurantiaca sp. nov., Sphingomonas aerolata sp. nov. and Sphingomonas faeni sp. nov., air- and dustborne and Antarctic, orange-pigmented, psychrotolerant bacteria, and emended description of the genus Sphingomonas. Int J Syst Evol Microbiol 53, 1253-1260.

Cui, X. L., Mao, P. H., Zeng, M., Li, W. J., Zhang, L. P., Xu, L. H. \& Jiang, C. L. (2001). Streptimonospora salina gen. nov., sp. nov., a new member of the family Nocardiopsaceae. Int J Syst Evol Microbiol 51, 357-363.

De Ley, J., Cattoir, H. \& Reynaerts, A. (1970). The quantitative measurement of DNA hybridization from renaturation rates. Eur J Biochem 12, 133-142.

Felsenstein, J. (1985). Conference limits on phylogenies: an approach using the bootstrap. Evolution 39, 783-789.

Huß, V. A. R., Festl, H. \& Schleifer, K. H. (1983). Studies on the spectrophotometric determination of DNA hybridization from renaturation rates. Syst Appl Microbiol 4, 184-192.

Jahnke, K.-D. (1992). Basic computer program for evaluation of spectroscopic DNA renaturation data from GILFORD System 2600 spectrophotometer on a PC/XT/AT type personal computer. J Microbiol Methods 15, 61-73.

Kimura, M. (1980). A simple method for estimating evolutionary rates of base substitutions through comparative studies of nucleotide sequences. J Mol Evol 16, 111-120.

Kimura, M. (1983). The Neutral Theory of Molecular Evolution. Cambridge: Cambridge University Press.

Lee, J. S., Shin, Y. K., Yoon, J. H., Takeuchi, M., Pyun, Y. R. \& Park, Y. H. (2001). Sphingomonas aquatilis sp. nov., Sphingomonas koreensis sp. nov. and Sphingomonas taejonensis sp. nov., yellow-pigmented bacteria isolated from natural mineral water. Int J Syst Evol Microbiol 51, 1491-1498.

Li, W. J., Zhang, Y. Q., Park, D. J., Li, C. T., Xu, L. H., Kim, C. J. \& Jiang, C. L. (2004). Duganella violaceinigra sp. nov., a novel mesophilic bacterium isolated from forest soil. Int $J$ Syst Evol Microbiol 54, 1811-1814.

Marmur, J. (1961). A procedure for the isolation of deoxyribonucleic acid from microorganisms. J Mol Biol 3, 208-218.

Marmur, J. \& Doty, P. (1962). Determination of the base composition of deoxyribonucleic acid from its thermal denaturation temperature. J Mol Biol 5, 109-118.

Moaledj, K. (1986). Comparison of Gram-staining and alternate methods, $\mathrm{KOH}$ test and aminopeptidase activity in aquatic bacteria: their application to numerical taxonomy. J Microbiol Methods 5, 303-310.

Rivas, R., Abril, A., Trujillo, M. E. \& Velazquez, E. (2004). Sphingomonas phyllosphaerae sp. nov., from the phyllosphere of Acacia caven in Argentina. Int J Syst Evol Microbiol 54, 2147-2150.

Saitou, N. \& Nei, M. (1987). The neighbor-joining method: a new method for reconstructing phylogenetic trees. Mol Biol Evol 4, 406-425.

Sasser, M. (1990). Identification of bacteria by gas chromatography of cellular fatty acids. USFCC Newsl 20, 16.

Shirling, E. B. \& Gottlieb, D. (1966). Methods for characterization of Streptomyces species. Int J Syst Bacteriol 16, 313-340.

Stackebrandt, E. \& Goebel, B. M. (1994). Taxonomic note: a place for DNA-DNA reassociation and 16S rRNA sequence analysis in the present species definition in bacteriology. Int J Syst Bacteriol 44, 846-849.

Takeuchi, M., Kawai, F., Shimada, Y. \& Yokota, A. (1993). Taxonomic study of polyethylene glycerol-utilizing bacteria: emended description of the genus Sphingomonas and new descriptions of Sphingomonas macrogoltabidus sp. nov., Sphingomonas sanguis sp. nov. and Sphingomonas terrae sp. nov. Syst Appl Microbiol 16, 227-238.

Takeuchi, M., Hamana, K. \& Hiraishi, A. (2001). Proposal of the genus Sphingomonas sensu stricto and three new genera, Sphingobium, Novosphingobium and Sphingopyxis, on the basis of phylogenetic and chemotaxonomic analyses. Int J Syst Evol Microbiol 51, 1405-1417.

Thompson, J. D., Gibson, T. J., Plewniak, F., Jeanmougin, F. \& Higgins, D. G. (1997). The CLUSTAL_X Windows interface: flexible strategies for multiple sequence alignment aided by quality analysis tools. Nucleic Acids Res 25, 4876-4882.

Ventosa, A., Marquez, M. C., Kocur, M. \& Tindall, B. J. (1993). Comparative study of "Micrococcus sp." strains CCM 168 and CCM 1405 and members of the genus Salinicoccus. Int J Syst Bacteriol 43, 245-248.

Yabuuchi, E., Yano, I., Oyaizu, H., Hashimoto, Y., Ezaki, T. \& Yamamoto, H. (1990). Proposals of Sphingomonas paucimobilis gen. nov. and comb. nov., Sphingomonas parapaucimobilis sp. nov., Sphingomonas yanoikuyae sp. nov., Sphingomonas adhaesiva sp. nov., Sphingomonas capsulata comb. nov., and two genospecies of the genus Sphingomonas. Microbiol Immunol 34, 99-119.

Yabuuchi, E., Kosako, Y., Fujiwara, N., Naka, T., Matsunaga, I., Ogura, H. \& Kobayashi, K. (2002). Emendation of the genus Sphingomonas Yabuuchi et al. 1990 and junior objective synonymy of the species of three genera, Sphingobium, Novosphingobium and Sphingopyxis, in conjunction with Blastomonas ursincola. Int J Syst Evol Microbiol 52, 1485-1496. 